\title{
PROTECTING POPULAR CONSTITUENT POWER: EXAMINING NEW ZEALAND'S ROLE IN THE CONSTITUTION-MAKING EPISODES OF THE COOK ISLANDS AND NIUE
}

\author{
Sarah Mead*
}

This article assesses the democratic legitimacy of the constitution-making processes that brought into being the Constitutions of the Cook Islands and Niue. New Zealand's role in the decolonisation of its former colonies has generally been seen as quite benign. New Zealand's status as an external actor, however, raises questions regarding the effect its influence had on the democratic legitimacy of the respective constitution-making processes.

Constituent power theory demands that a constitution is the product of the popular political will; an act of self-determination undertaken by the people, for the people. This article argues that the existence of external influence in the constitution-making process is not necessarily at odds with this. In so far as external actors do not displace the people's constituent power but rather enhance it, there is no reason to exclude such influence; there may even be reason to encourage it.

By drawing on New Zealand's experience in decolonisation, this article ultimately advances a twostage model for constitution-making in the context of small, dependent non-self-governing island states. As ongoing political ties with an external state are often sought, the aim of the model is to provide an avenue for that external state to participate in or contribute to the constitution-making process while maintaining the process's democratic legitimacy.

* $\quad$ BA/LLB(Hons). This (revised) article was submitted in fulfilment of the LLB(Hons) programme at Victoria University of Wellington. The author wishes to thank Joel Colón-Ríos and Professor Tony Angelo for their support and guidance in writing this article. 


\section{INTRODUCTION}

During the 1960s and 1970s, a wave of constitution-making washed across the Pacific region as several of the world's remaining colonised territories welcomed in a new era of independence in some form. Two such countries were the Cook Islands and Niue which, in 1965 and 1974 respectively, became self-governing states in free association with New Zealand. In both cases, this significant political shift was accompanied by the coming into force of national constitutions.

This article will explore the processes that brought into being the Constitutions of the Cook Islands and Niue. At decolonisation, both states rejected full independence and explicitly sought ongoing political ties with New Zealand as a condition to their advancement towards selfgovernment. As a result, New Zealand recognised a role for itself in the constitution-making processes and exerted significant influence throughout. Though New Zealand's role in this regard has generally been seen as quite benign, its status as an external actor raises questions regarding the effect its influence had on the democratic legitimacy of the resulting constitutional regimes.

Classical constitutional theory locates constituent power - that is, the power to frame a constitution - in the people or the nation. By making those who will be bound by the constitution the source of its authority, the democratic legitimacy of the constitution is ensured. A democratically legitimate constitution is one that the people "give to themselves". For some states, the implicit exclusion of external actors in this classical notion of constituent power is unproblematic - constitution-making will proceed as an exclusively national exercise with nominal regard for external actors or states. For small dependent states such as the Cook Islands and Niue however, external actors simply cannot be ignored in the constitution-making process. For these states, the importance of their ties with an external state require recognition; their fragile political, economic and social realities demand a more flexible and responsive conception of constituent power.

This article aims to assess the democratic legitimacy of the constitution-making processes behind the Constitutions of the Cook Islands and Niue, taking account of New Zealand's role. While this article accepts that the processes may have lacked democratic legitimacy, it will challenge the assumption behind classical constituent power theory that this is the inevitable result of New Zealand's influence. A strict conceptualisation of constituent power fundamentally limits the analysis of constitution-making and fails to recognise the potential for external influence to enhance the people's role in this process.

With a view to establishing a more nuanced (and helpful) approach to assessing the effect of external influence, this article will explore the possibility of reconciling the theory of constituent power with the reality of external influence in constitution-making. Ultimately it will argue that reconciliation is possible, but that external influence must be carefully managed to maintain the democratic legitimacy of the process. An analytical framework aimed at identifying democratically 
legitimate external intervention in the constitution-making process will be advanced, and it is on this basis that the constitutional experiences of the Cook Islands and Niue will be assessed.

Though critiquing New Zealand's role in the decolonisation process of its former colonies is a key component of this article, it is by no means the primary aim. In 2010, the United Nation's General Assembly declared 2011-2020 the Third International Decade for the Eradication of Colonialism. ${ }^{1}$ Despite the best efforts of the United Nations and the Committee of 24 (Special Committee on Decolonization), there remain 15 non-self-governing island states. ${ }^{2}$ Though these island states do not appear to be getting closer to completing the decolonisation process, ${ }^{3}$ in the instance that they do, it is likely that this will be on the condition that political ties with the colonial power will continue into the future. ${ }^{4}$ For constitution-making, this presents a challenge. By seeking ongoing ties with an external state, careful attention must be paid to ensure that the constitution is the product of a popular exercise of constituent power. Towards addressing this challenge, this article will explore how constitution-making in the context of small, dependent non-self-governing island states can include a role for an external power, while maintaining the process's democratic legitimacy.

This article proceeds as follows. Part II introduces the case studies, the Cook Islands and Niue, and gives some background to their respective constitution-making processes. Part III then establishes the article's theoretical compass points. The key concept of popular constituent power is introduced and an account of the procedurally normative conception of democratic legitimacy is advanced. In Part IV, classical and contemporary conceptions of constituent power in constitutional theory are considered with regards to the constitution-making episodes of the Cook Islands and Niue. In light of the difficulties presented by these conceptions, the article goes on to advance a

1 Third International Decade for the Eradication of Colonialism GA Res 65/119, A/Res/ 65/119 (2011). The first international decade was proclaimed by International Decade for the Eradication of Colonialism GA Res 43/47, A/Res/43/47 (1988). The second international decade was proclaimed by Second International Decade for the Eradication of Colonialism GA Res 55/146, A/Res/55/146 (2000).

2 The remaining non-self-governing island states are: American Samoa, Guam, Pitcairn, Tokelau, Anguilla, Bermuda, British Virgin Islands, US Virgin Islands, Cayman Islands, Falkland Islands (Malvinas),

Montserrat, and Turks and Caicos, St Helena, French Polynesia and New Caledonia. Gibraltar and Western Sahara are also non-self-governing territories, but are excluded from the scope of this article, the focus of which is island states. See United Nations "United Nations List of Non-Self-Governing Territories" $\langle$ http://www.un.org>.

3 Perhaps with the exception of New Caledonia. Under the 1998 Noumea Accord, a referendum will be held between 2014 and 2019 to decide the future status of the territory. See Nic MacLellan "The Noumea Accord and Decolonisation in New Caledonia" (1999) 34 The Journal of Pacific History 245. With regards to the Falkland Islands, decolonisation is hampered by a territorial dispute.

4 Since 1984, the only small territories to struggle and obtain full independence have been East Timor, Montenegro and Kosovo. See Godfrey Baldacchino "'Upside Down Decolonization' in Subnational Island Jurisdictions: Questioning the 'Post' in Postcolonialism" (2010) 13 Space and Culture 188 at 192. 
more flexible conception of constituent power, which is considered more appropriate to assess the effect of external influence on the democratic legitimacy of the constitution-making process. In Part $\mathrm{V}$, the constitutional experiences in the Cook Islands and Niue are analysed according to this more flexible conception. Building on the conclusions from this analysis and looking towards the future, the final part of this article proposes a model of constitution-making that is considered more appropriate for dependent non-self-governing island states wishing to undergo constitutional change while retaining ties with an external state.

\section{CONSTITUTION-MAKING IN THE COOK ISLANDS AND NIUE}

\section{A Background}

The Cook Islands and Niue are two island states located in the South Pacific Ocean. By proclamation dated 10 June 1901 both were formally included within the boundaries of the "Colony of New Zealand". ${ }^{5}$ Though the Cook Islands and Niue accepted a shift towards self-government (with varying degrees of enthusiasm), it was New Zealand, not the colonies, which pushed for the latter to become self-governing following pressure from the United Nations (UN). ${ }^{6}$

In 1960, New Zealand signed the UN Declaration on the Granting of Independence to Colonial Countries and Peoples (the Declaration). The Declaration recognised that "all peoples have the right to ... freely determine their political status", ${ }^{7}$ and was based on an assumption that full independence, if given the option, would be the desired option of the world's remaining colonies. It stated that: ${ }^{8}$

[I]mmediate steps shall be taken, in United Nations Trust and Non-Self-Governing Territories or all other territories which have not yet attained independence, to transfer all powers to the peoples of those territories.

The Declaration left colonial powers little room to manoeuvre, stating that "inadequacy of political, economic, social or educational preparedness should never serve as a pretext for delaying independence". 9

Having signed the Declaration, New Zealand felt an acute sense of pressure to comply with its terms as soon as possible. ${ }^{10}$ The local people of the Cook Islands and Niue did not however, as

5 Cook Islands Boundaries and Inclusion in New Zealand Proclamation 1901.

6 Baldacchino, above $\mathrm{n}$ 4, at 190.

7 Declaration on the Granting of Independence to Colonial Countries and Peoples GA Res 1514, XV A/Res/1514 (1960), art 2.

8 Article 5

9 Article 3 
suggested in the Declaration, display an apparent "yearning for freedom", nor was there any suggestion of a threat of "conflicts resulting from the denial" of their freedom. ${ }^{11}$ Rather, they explicitly demanded the maintenance of strong ties with New Zealand.

To take account of this reality, the UN General Assembly passed a resolution later in 1960 recognising alternative political arrangements (aside from full independence) that would afford the decolonising state the requisite full measure of self-government. ${ }^{12}$ On this basis, the New Zealand Minister of Island Territories presented a speech to the Cook Islands Legislative Assembly (CILA) in 1962 (which was later sent to the Niue Island Assembly (NIA)), on the colonies' constitutional futures. The Assemblies were presented with four options: (1) full independence; (2) Polynesian federation; (3) integration with New Zealand; or (4) internal self-government. ${ }^{13}$ The Minister expressed the view "that it would be in the best interests of the Cook Islands [and Niuean] people to keep the present link with New Zealand, but to have full internal self-government". ${ }^{14}$

In 1962, the CILA and NIA passed resolutions stating that internal self-government, rather than full independence, was their preference. Towards the attainment of that goal, the New Zealand Government prepared "a programme for the future", which included a timetable mapping out a careful transfer of power over the course of three years towards self-government. ${ }^{15}$ The Cook Islands went ahead with constitutional change loosely according to New Zealand's proposal. Niue, however, accepted internal self-government in principle, but demanded a more gradual approach.

Pragmatic reasons ultimately informed the respective Assemblies' rejection of full independence. At the time of decolonisation, both countries had very small populations which persist today. Niue, with just one island and a land mass of 260 square kilometres, had a total

10 Terry Chapman The Decolonisation of Niue (Victoria University Press and NZ Institute of International Affairs, Wellington, 1976) at 19.

11 Declaration on the Granting of Independence to Colonial Countries and Peoples, above n 7.

12 The resolution recognised three decolonisation options: "A Non-Self-Governing Territory can be said to have reached a full measure of self-government by: (a) Emergence as a sovereign independent state; (b) Free association with an independent State; or (c) Integration with an independent State." Principles which should guide members in determining whether or not an obligation exists to transmit the information called for under Article 73 e of the Charter GA Res 1541, XV (1960).

13 Sir Leon Gotz, Minister of Island Territories "Future Political Development" (speech to Cook Islands Legislative Assembly, Cook Islands, 11 July 1962) as reported in The Proceedings of the Fifth Session of the Legislative Assembly of the Cook Islands (1962) at 101-108.

14 At 105

15 Cook Islands Legislative Assembly Future Political Development (Cook Islands Legislative Assembly Paper No 18, 1963) (presented by the President of the CILA "by direction of the Hon Minister of Island Territories"). 
population of 4,000 people. ${ }^{16}$ The Cook Islands had a larger population of about 18,000 people, ${ }^{17}$ but this population was spread throughout 15 islands scattered over approximately two million square kilometres of ocean. The small size, lack of natural resources and geographical isolation of these island states at decolonisation meant that economic development was severely limited. Owing to heavy subsidies from the New Zealand government along with remittances from family in New Zealand however, neither countries' living standards reflected this reality. When constitutional change was suggested in 1962 therefore, it is not surprising that the island states' future relationship with New Zealand was a key concern of the local people.

\section{$B$ The Constitution-Making Processes}

\section{The Cook Islands}

The constitution-making process in the Cook Islands was, by all accounts, rapid, taking effect a mere three years after constitutional change was first suggested by the New Zealand Government. ${ }^{18}$

Addressing the CILA in 1962, the Minister of Island Territories made clear that, with regards to constitutional change, "the final decision will have to be made by the people of the Cook Islands". ${ }^{19}$ The Minister cited a desire, however, to "cooperate with the United Nations", ${ }^{20}$ and a feeling on the part of the Government "not to postpone matters too long". ${ }^{21}$ Two days later, the CILA passed a resolution in favour of self-government. ${ }^{22}$

After accepting the timetable towards self-government prepared by the New Zealand Government, the CILA requested expert assistance. Three advisers were chosen: Professor Aikman, Professor Davidson and Mr Wright. ${ }^{23}$ Following a visit of nine days, the three advisers prepared a report comprising 44 recommendations for constitutional change. ${ }^{24}$ The report stated that, as far as

16 Niue Statistics "Population" <http://www.spc.int>.

17 Statistics Office, Rarotonga, Cook Islands "Total Population and Land Area by Island" <http://www.spc.int>.

18 Cook Islands Constitution Act 1964, sch 1.

19 Gotz, above n 13, at 106.

20 At 104

21 At 106.

22 Cook Islands Legislative Assembly Resolution of the Cook Islands Legislative Assembly (13 July 1962).

23 Professor Aikman was Professor of Constitutional Law at Victoria University. Professor Davidson was Professor of Pacific History at Australia National University and had acted as adviser to the Government of Western Samoa preceding independence. Mr Wright had acted as High Commissioner for New Zealand in Western Samoa and Secretary of Island Territories.

24 CC Aikman, JW Davidson and JB Wright "Report to the Members of the Legislative Assembly of the Cook Islands on Constitutional Development" (1999) 30 VUWLR 519. 
the advisers could judge, "the recommendations ... for constitutional development are in full accordance with the wishes of the Cook Islands people, as expressed by ... their elected representatives". ${ }^{25}$ The CILA approved the recommendations in the report, with only minor modifications. ${ }^{26}$ The Constitution, which was drafted in New Zealand in collaboration with the advisers (in English only), was based on this report.

After passing its first reading in the New Zealand Parliament, the proposed Constitution was sent to the Select Committee on Island Territories sitting in Wellington. ${ }^{27}$ Along with hearing submissions from Cook Islanders resident in New Zealand, the Committee welcomed a delegation of four CILA members. ${ }^{28}$

On 17 November 1964, the Cook Islands Constitution Act was passed by the New Zealand Parliament. As stipulated in the Act, the Constitution was to come into force following the election of a new CILA. ${ }^{29}$ At the first meeting of the newly elected CILA, three resolutions were passed requesting that the New Zealand Parliament amend the Constitution. ${ }^{30}$ Having given effect to the requested amendments, self-government in the Cook Islands was proclaimed on 27 July 1965 to come into effect on 4 August 1965. ${ }^{31}$

\section{Niиe}

The Constitution of Niue was the result of a much slower constitution-making process than that in the Cook Islands. ${ }^{32}$ Despite passing a resolution in 1962 accepting that self-government was best

25 At 522.

26 Cook Islands Legislative Assembly Cook Islands Legislative Assembly Paper No 45 (1963).

27 The Select Committee, established on 10 August 1964, met 11 times over period of a week, and recorded 196 pages of typescript in the questioning of witnesses. The members included the Prime Minister, the Leader of the Opposition and Minister of Island Territories: Island Territories Committee Report of Evidence Given before Island Territories Committee, Island Territories Committee - Cook Islands Constitution Bill (23 September 1964).

28 The delegation consisted of Hon D C Brown, Hon Makea Nui Teremoana Ariki, Hon David Hosking, Hon Naine Rere, and was accompanied by Mr Dare, the Resident Commissioner. Professor Aikman and $\mathrm{Mr}$ Wright were also in attendance.

29 Cook Islands Constitution Act 1964, s 1. The relevant election was held on 20 April 1965.

30 The amendments included a change to the candidature rules for election to the CILA, a change to the number of Cabinet Ministers from five to seven, the establishment of a House of Arikis (to function as a consultative body), and changes to the role of the New Zealand High Commissioner to include acting as the representative of the Queen. See Cook Islands Constitution Amendment Act 1965 (passed on 7 June 1965).

31 Cook Islands Constitution Act Commencement Order 1965.

32 Niue Constitution Act 1974. 
for Niue (and asking that the other three alternatives be "buried forever"), ${ }^{33}$ the NIA demanded a "piecemeal" approach to constitutional development. ${ }^{34}$

After receiving the timetable prepared by the New Zealand Government outlining steps to attaining self-government, the NIA requested expert assistance in 1963. Two years later, the New Zealand Government sent Professor Aikman and Mr McEwen to Niue (after constitutional change had been effectively "dealt" with in the Cook Islands). ${ }^{35}$ Early on, it became apparent to the advisers that the short time frames proposed in the timetable had created "a great deal of concern". ${ }^{36}$ The advisers' first report therefore suggested that any formal constitutional developments in Niue be put on hold. ${ }^{37}$

Four years later, the Assembly passed a motion to reconsider New Zealand's proposal for constitutional change. At this point, Professor Quentin-Baxter took over as constitutional adviser to the NIA ${ }^{38}$ During discussions with the NIA, the Assembly made clear to Professor Quentin-Baxter that it was still "by no means committed to the view that there should be any further constitutional changes in the immediate future". ${ }^{39}$ After extensive local consultation (which predominantly confirmed the NIA's uncertain stance), Professor Quentin-Baxter recommended to the New Zealand Government that formal constitutional development again be put on hold.

Developments in the early 1970 s contributed to an increasing sense of confidence and positivity on the Island towards constitutional change. In June 1972, Niue received a UN Visiting Mission which led to the Select Committee on Constitutional Development (set up by the Niuean Government) taking action. After hearing submissions from the public, the Committee established a timetable towards self-government which was subsequently approved by the New Zealand Government and the Fourth Committee of the UN General Assembly. Recognising that constitutional development was no longer "paralysed by the people's deep anxiety" during his

33 Niue Assembly Minutes from the Niue Island Assembly (23 August 1962) at 12[20].

34 Chapman, above n 10, at 14.

35 Professor Aikman had formerly advised the CILA on the Cook Islands Constitution (see above $\mathrm{n} 23$ ). Mr McEwen was Secretary of Island Territories.

36 CC Aikman and JM McEwan A Report to the Minister of Island Territories on the Constitutional Development of Niue (Department of Island Territories, 1965) at 2[5].

37 At 2[6].

38 RQ Quentin Baxter was a Professor of Law at Victoria University of Wellington.

39 RQ Quentin-Baxter "Report to the Niue Island Assembly on the Constitutional Development of Niue" [1971] AJHR A4 at 6[6]. 
second visit in $1974,{ }^{40}$ Professor Quentin-Baxter recommended that the constitution be prepared at the request of the NIA.

The Constitution of Niue, drafted in New Zealand, was informed by Professor Quentin-Baxter's second report. After passing its first reading in the New Zealand Parliament, the Select Committee charged with receiving submissions on the proposed Constitution sat in both Wellington and Niue. ${ }^{41}$ Following generally positive feedback, the New Zealand Parliament passed the Niue Constitution Act on 29 August 1974, to come into effect following an affirmative popular referendum. On September 3 1974, 65.4 per cent voted in favour of Niue's new constitutional arrangements, with 34.6 per cent against. ${ }^{42}$ The Constitution entered into force by Proclamation on 19 October $1974 .{ }^{43}$

\section{The Constitutions}

The Constitutions are Schedules to Acts of the New Zealand Parliament that were made part of the law of both New Zealand, and the Cook Islands and Niue respectively. The Acts conferred plenary powers on the respective governments of the Cook Islands and Niue. By passing these Acts, the New Zealand Parliament irrevocably removed its power to legislate for its former colonies, thereby establishing the Cook Islands and Niue as fully internally self-governing states. Though the New Zealand Parliament could amend the Acts by simple majority, such amendments would only have effect in New Zealand. ${ }^{44}$ Amendments made to the Constitution Acts by the CILA or NIA are not made to the respective New Zealand Acts.

The Constitutions of the Cook Islands and Niue share, at least at a superficial level, many similarities. In both instances, what can be readily identified as the Constitution is contained in a Schedule to an Act of the New Zealand Parliament. The Constitutions provide for selfgovernment, ${ }^{45}$ while allowing for continued association with New Zealand under a common Head of State (the Queen in Right of the Realm of New Zealand), ${ }^{46}$ common New Zealand citizenship, ${ }^{47}$

40 RQ Quentin-Baxter "Second Report to the Niue Island Assembly on the Constitutional Development of Niue" (1999) 30 VUWLR 577 at 580.

41 Alison Quentin-Baxter "Making Constitutions, From the Perspective of a Constitutional Adviser" (2002) 33 VUWLR 237 at 260.

42 Voter turnout for the referendum was 97 per cent. See Report of the United Nations Special Mission to Observe the Act of Self-Determination in Niue XXII A/9623/Add 5 (1974).

43 Niue Constitution Act Commencement Order 1974.

44 The Constitution of Niue does leave open the possibility for the New Zealand Parliament to amend its Constitution with the NIA's request and consent (art 36), but this provision has not been used for several decades. The Cook Islands Constitution originally had a similar provision, but this was repealed in $1980-$ thereby removing any ability for the New Zealand Parliament to legislate for the Cook Islands.

45 Cook Islands Constitution Act 1964, s 3; Niue Constitution Act 1974, s 3.

46 Cook Islands Constitution Act 1964, s 2; Niue Constitution Act 1974, s 1. See Letters Patent Constituting the Office of Governor-General of New Zealand (28 October 1983), SR 1983/225 (as amended SR 1987/8 
and a continuing responsibility on the part of New Zealand for each states' external affairs and defence. ${ }^{48}$ The Constitutions further establish a parliamentary system of government, with responsibility for executive authority vested in a Cabinet of Ministers chosen from a fully elected Legislative Assembly and headed by the Premier.

Owing to the island states' unique characteristics and constitution-making processes, there are of course several notable differences between the Constitutions. The most prominent for the purposes of this article relate to the ongoing relationship of the Cook Islands and Niue with New Zealand. The Niue Constitution Act includes a provision for ongoing "necessary economic and administrative assistance to Niue" from New Zealand, ${ }^{49}$ and regular consultation between the two governments. ${ }^{50}$ The Cook Islands Constitution lacks any such provisions.

\section{CONSTITUTIONAL THEORY}

\section{A Democratic Legitimacy and Constituent Power}

This article defends a procedurally normative conception of democratic legitimacy in constitution-making, the criterion for which is the concept of popular constituent power.

Constituent power, or constitution-making power, "is the political will, whose power or authority is capable of making the concrete, comprehensive decision over the type and form of its own political existence". ${ }^{51}$ Writing during the French Revolution, Sieyès identified "the people" or "the nation" as the subjects of constituent power (le pouvoir constituant).$^{52}$ In doing so, he heralded an important shift in constitutional theory. Where previously public power had relied on external sources of authority (ie religion) for legitimation, Sieyès demanded that the conscious willing of the people could provide that authority, stating that "[t]he national will ... never needs anything but its own existence to be legal. It is the source of all legality." 53

Constitutional theory rests on an important distinction between constituent (constitutionmaking) power and constituted (law-making) power. Constituted power (which includes executive,

and SR 2006/224). See generally Laws of New Zealand "Pacific States and Territories: Cook Islands" (online ed) at [29]; and Elisabeth Perham "Citizenship laws in the Realm of New Zealand" (2011) 9 NZYIL 219.

47 Cook Islands Constitution Act 1964, s 6; Niue Constitution Act 1974, s 5.

48 Cook Islands Constitution Act 1964, s 5; Niue Constitution Act 1974, s 6.

49 Niue Constitution Act 1974, s 7.

50 Section 8.

51 Carl Schmitt Constitutional Theory (Duke University Press, Durham, 2007) at 125.

52 Emmanuel Joseph Sieyès What is the Third Estate? (Pall Mall Press, London, 1963) at 58.

53 At 126. 
legislative and judicial authority) remains permanently subordinate to constituent power, which conversely can never be constrained nor exhausted. As explained by Schmitt: ${ }^{54}$

All constitutionally constituted powers and competencies are based on the constitution-making power.

However it can never constitute itself in terms of constitutional law. The people, the nation, remains the origin of all political action, the source of all power...

The connection between constituent power and democracy can be readily identified. Democracy requires that all eligible citizens participate equally in the creation of the laws to which they are subject. The theory of constituent power demands that the constitution, the fundamental law of society, is the product of the political will of the people (those who will be subject to the constitution). By permanently locating the constitution-making power in those who are bound by the constitution, the theory of constituent power effectively guarantees the democratic nature of the constitutional regime. "Constituent politics", Kalyvas explains, "might be seen as the explicit, lucid self-institution of society, whereby the citizens are jointly called to be the authors of their constitutional identity and to decide the central rules and higher procedures that will regulate their political and social life". 55

There is sound reason to be concerned with democracy at the level of constitution-making. As Colón-Ríos explains, "if there is a deficit of democracy at the level of the fundamental laws, the democratic legitimacy of the constitutional regime is inevitably put into question". ${ }^{56}$ Recognition of the importance of democratic process in relation to the creation of ordinary laws thus necessarily requires that attention be paid to how the relevant fundamental law was created.

Democratic legitimacy in constitution-making is therefore understood in this article as meaning the extent to which a constitution can be seen as the manifestation of the political will of the people it purports to bind - or in other words, the manifestation of an exercise of popular constituent power. ${ }^{57}$

54 Schmitt, above n 51, at 128 (emphasis added).

55 Andreas Kalyvas "Popular Sovereignty, Democracy, and the Constituent Power" (2005) 12(5) Constellations 223 at 237.

56 Joel Colón-Ríos "The Second Dimension of Democracy: The People and Their Constitution" (2009) 2(2) Baltic Journal of Law \& Politics 1 at 9.

57 The scope of this article is limited to those instances of constitution-making where "the people" is an already recognised entity (so it would not realistically apply to the Falkland Islands). Popular constituent power as a criterion for assessing democratic constitution-making presupposes a people or a nation. Where this is not already established (for example, where a state's borders are disputed), this criterion is of limited utility as it is difficult to identify "a people" who are to give to themselves a constitution. The problem of "democratic beginnings" arises. See generally Hans Agné "Democratic founding: We the people and the others" (2012) 10 Int J Const L 836; and Zoran Oklopcic "Constitutional (Re)Vision: Sovereign Peoples, 
Popular constituent power "represents an ideal and pure type of democratic constitutional making". ${ }^{58}$ Constitution-making however rarely occurs in ideal "textbook" conditions. ${ }^{59}$ Reality thus demands that democratic legitimacy in constitution-making be treated as a matter of degree. For a constitution to enjoy democratic legitimacy, however, at a minimum the people must be responsible for defining its fundamental elements. ${ }^{60}$ In this regard, Schmitt identifies certain "fundamental political decisions" that form the basis of a constitution. ${ }^{61}$ Referencing the Weimar Constitution, Schmitt identifies those decisions pertaining to whether Germany would be a republic or a monarchy, a federal or unitary system, or a parliamentary or presidential system, as fundamental to the resulting constitutional regime. These decisions define the "people's form of political existence and thus constitute the fundamental prerequisites for all subsequent norms". ${ }^{62}$

\section{EXTERNAL INFLUENCE AND DEMOCRATIC LEGITIMACY}

Strictly understood, constituent power theory dictates that, as outsiders will not be bound by the resulting constitutional regime, their involvement detracts from the process's democratic legitimacy. A strict conception of popular constituent power is dominant in classical constitutional theory. Sieyès, the father of constituent power theory, implicitly excludes a role for outsiders in the constitution-making process by identifying the "nation" as the exclusive source of constituent power. As explained by Schmitt, in a democracy, "[t]he people are the bearer of the constitutionmaking power and, as such, grant themselves their constitution". ${ }^{63}$ As explained by Agné, "the critical, though not always explicit, assumption in this literature is that only those can exercise legitimate constituent powers who will become citizens in the future state". ${ }^{64}$

On a strict conception of popular constituent power, it is clear that, given New Zealand's involvement, the Constitutions of the Cook Islands and Niue would be considered (to varying

New Constituent Powers, and the Formation of Constitutional Orders in the Balkans" (2012) 19(1) Constellations 81 .

58 Kalyvas, above n 55, at 238.

59 See Jon Elster "Forces and Mechanisms in Constitution-Making" (1995) 45 Duke LJ 123 at 138.

60 The focus of this article is democracy at the level of constitution-making. However, while democracy at the level of constitution-making (which may extend to amendments to the constitution's fundamental elements) is required for a constitution to enjoy democratic legitimacy, it will not determine the overall democratic legitimacy of a constitution. It is entirely possible for the constitution-making process to be highly democratic, and for the people to choose a substantively undemocratic constitution.

61 Schmitt, above n 51, at 78.

62 At 78.

63 At 225

64 Hans Agné "Democratic founding: We the people and the Others" (2012) 10 Int J Const L 836 at 852 (emphasis added). 
degrees) the products of processes lacking in democratic legitimacy. This conclusion may be fair; there is much to criticise in relation to the constitution-making processes in the Cook Islands and Niue. To base this conclusion simply on the existence of external influence in the constitutionmaking process is, however, problematic.

At decolonisation, the Cook Islands and Niue attached "the highest importance" to the maintenance of their association with New Zealand. ${ }^{65}$ They explicitly sought to retain New Zealand citizenship and assurances that they would continue receiving economic and administrative assistance. A role for New Zealand was therefore to be expected in the constitution-making episodes of the Cook Islands and Niue because of the ongoing political relationship sought.

The involvement of New Zealand in the constitution-making processes of Cook Islands and Niue could be disregarded today as something from a bygone era; as examples of the final gasps of colonisation before the world entered a more enlightened age where such intervention is considered simply inappropriate. On such a view, the existence of external influence in these processes would not be seen as challenging the applicability of a strict conception of popular constituent power. If anything, the case studies would be treated as affirming the normative value of a strict conception as a conclusion that the processes lacked democratic legitimacy would accord with a sense that something was amiss in these cases.

A cursory glance over the extent of external influence in modern constitution-making, however, warns against any hasty conclusions to that effect. The orientation of "constitutional civility", 66 which informed the processes in the Cook Islands and Niue, takes a new form today as "democracy promotion", "peace building" or "transitional justice". Recent constitution-making episodes, such as those in Iraq, ${ }^{67}$ Bosnia-Herzegovina ${ }^{68}$ East Timor and Sudan, ${ }^{69}$ reveal the extent to which external

65 Aikman, Davidson and Wright, above n 24, at 521[5]; similarly expressed by Quentin-Baxter regarding Niue. He notes that "the most important question for Niue will always be its relationship with New Zealand": see Quentin-Baxter, above n 40, at 578.

66 "Constitutional civility" is a constitutional orientation that often informed the creation of decolonisation/independence constitutions. A constitution is treated by a departing colonial power as a means of establishing modern state institutions in their image in the colony: see Sara Kendall "'Constitutional Technicity': Displacing Politics through Expert Knowledge" [2013] Law, Culture and the Humanities 1 at 2 .

67 See Noah Feldman "Imposed Constitutionalism" (2005) 37 Conn L Rev 857; Andrew Arato Constitutionmaking Under Occupation: The Politics of Imposed Revolution in Iraq (Colombia University Press, New York, 2009); and Philipp Dann and Zaid Al'Ali "The Internationalized Pouvoir Constituant - ConstitutionMaking Under External Influence in Iraq, Sudan and East Timor" (2006) 10 Max Planck UNYB 423.

68 See Zoran Oklopcic "After the People: The Demise of Self-Determination, A New Constitutional Theory and Tradeoffs of Peoplehood" (Thesis submitted for the degree of Doctor of Juridical Science, University of Toronto, 2008); and Zoran Oklopcic "Constitutional (Re)Vision: Sovereign Peoples, New Constituent Powers, and the Formation of Constitutional Orders in the Balkans" (2012) 19(1) Constellations 81.

69 See Dann and Al'Ali, above n 67. 
actors are often involved in the process. Be it through the offering of expert advice or through the determination of the constitution's procedural or substantive framework, external actors consistently have a part to play in modern constitution-making. This has led Dann and Al'Ali to suggest the emergence of an "internationalised pouvoir constituant" ${ }^{70}$ As explained by Preuss, no longer can state constitutions be considered (if they ever could) as "purely domestic instruments of government of a nation-bound population which exercises its right to national self-determination without concern of its regional or global surroundings". ${ }^{71}$

To accept a classical (strict) understanding of popular constituent power, therefore, requires accepting that not only the case studies, but also many examples of modern constitution-making, fall outside the analytical ambit of constitutional theory. A failure to operate as an analytical tool in reality risks rendering constitutional theory irrelevant, and thus a strict conception of constituent power must be rejected.

\section{A Enlarged(Loose) Conception of Constituent Power}

Recognising the gap between constitutional theory and the realities of constitution-making, Oklopcic has advanced an argument in favour of "enlarging" constituent power beyond the people to reflect the "multiplicity of constituent powers, not only from within, but also from without". ${ }^{72}$

Following an analysis of external actors in the constitutional experiences of the Balkan states, Oklopcic posits that the number of constituent powers involved in a constitution-making episode must be pluralised and enlarged beyond the people. Drawing on Loughlin's concept of political prudence, ${ }^{73}$ Oklopcic argues that enlarging the notion of constituent power to include external actors would amount to a necessary "prudential attunement" of theory with reality. A re-imagining of constituent power would involve perceiving the constituent not as just the people, but as "an assemblage of political powers". ${ }^{74}$ The fundamental link between the people and constituent power would thus be severed.

Such an "attunement" finds support in the sociological approach to understanding constituent power advanced by Thornhill. ${ }^{75}$ Through his analysis of the theory of constituent power in the

70 At 423

71 Ulrich K Preuss "Perspectives on Post-Conflict Constitutionalism: Reflections on Regime Change Through External Constitutionalization" (2006-2007) 51 NYL Sch L Rev 467 at 490.

72 Oklopcic "Constitutional (Re)Vision: Sovereign Peoples, New Constituent Powers, and the Formation of Constitutional Orders in the Balkans", above n 68, at 97.

73 See Martin Loughlin The Idea of Public Law (Oxford University Press, New York, 2004).

74 Oklopcic "Constitutional (Re)Vision: Sovereign Peoples, New Constituent Powers, and the Formation of Constitutional Orders in the Balkans", above n 68, at 81.

75 Chris Thornhill "Contemporary constitutionalism and the dialectic of constituent power" (2012) 1 GlobCon 369. 
context of a perceived emergent transnational constitution, Thornhill argues that a literalistic understanding of the relation between political concepts and the political system must be abandoned to make way for a more sociologically adaptive approach. By linking classical (strict) conceptions of constituent power to a political need in the 18th century to produce constitutional legitimacy without reliance on external principles or social attachments, Thornhill explains why the concept was necessarily limited to the people and why, in view of the "post-state transnational order", it need not necessarily remain so.

Constituent power is a political concept that ought to be capable of evolution to reflect political reality; fossilising the concept risks rendering it relevant only to academics. There is however a real risk that the normative value of popular constituent power will be hollowed out if expanded beyond the people. Oklopcic recognises that enlarging constituent power involves "an obvious and unarticulated tradeoff". ${ }^{76}$ He explains: ${ }^{77}$

What we acquire in our prudential attunement to the realities of external constituent influence, we lose on the side of normative and rhetorical benefits stemming from the vocabulary of constituent power of the sovereign people.

He argues however that a recalibration of theory with reality should not be frustrated by normative concerns, asserting that "there is no reason why constitutional theory should be invested in a particular normative programme". ${ }^{78}$ Contrary to this claim, there appears to be very good reasons for constitutional theory to be invested in some form of normative programme.

By directly connecting the citizen to the constitution, popular constituent power provides a powerful rhetoric in support of a participative and active citizenry committed to constitutional enforcement. Violations of the constitution are more likely to be challenged, rendering the constitution more effective. ${ }^{79}$ As it always remains with the people, popular constituent power can act as a constant reminder to national leaders that they, and the pouvoir constitue in general, ultimately remain subject to the will of the people. At the international level, recognition that the people, the nation, are the only holders of constituent power sends a strong message to powerful states to exercise restraint before considering intervening in the constitution-making episodes of foreign countries. ${ }^{80}$

76 Oklopcic "Constitutional (Re)Vision: Sovereign Peoples, New Constituent Powers, and the Formation of Constitutional Orders in the Balkans", above n 68, at 97.

77 At 97.

78 At 93.

79 Tom Ginsburg, Zachary Elkins and Justin Blount "Does the Process of Constitution-Making Matter?" (2009) 5 Annu Rev Law Soc Sci 201 at 216.

80 Oklopcic "Constitutional (Re)Vision: Sovereign Peoples, New Constituent Powers, and the Formation of Constitutional Orders in the Balkans", above n 68, at 89. 
There is a need to accept and account for the fact that external actors can strongly influence the constitution-making process. To fail to do so leaves open the potential for abuse and risks rendering constitutional literature irrelevant. By weakening the link between constituent power and the people however, academics such as Oklopcic ultimately go too far. To retain the valuable normative benefits of popular constituent power, it must remain in the hands of the people who will be bound by the resulting constitutional regime.

\section{B A Flexible Conception of Constituent Power: Towards a New Analytical Framework}

In order to recognise and make space for external actors in the constitution-making process while retaining the normative benefits of popular constituent power, a strict exclusionary conception of popular constituent power and a loose conception that severs the link between constituent power and the people must be rejected. A democratically legitimate constitutional regime requires that the people subject to that regime co-institute it. There is nothing implicit in this requirement however, that demands the exclusion of external actors. Recognising a role for external actors in constitutionmaking does not require departing from the fundamentals of constitutional theory. It does however require a more nuanced understanding of how constituent power is exercised.

The traditional theory of constituent power implicitly excludes external influence in the constitution-making process because it is seen as displacing a popular (or internal) exercise of constituent power. Where external influence is not carefully managed such a displacement will likely occur, but this will not necessarily be the case. The people's capacity to exercise constituent power is not decreased simply because an external actor has influenced the constitution-making process; the existence of one is not necessarily at the expense of the other. Agné explains: ${ }^{81}$

That actor A affects actor B does not by itself mean that there are fewer or less important possibilities of action available to $\mathrm{B}$, nor that $\mathrm{B}$ is prevented from performing any particular action. The effect caused by A may indeed have been to increase B's possibilities to act freely.

Rather than falling back on generalised verdicts, analysing the democratic legitimacy of external influence in constitution-making requires a particularised assessment. The focus needs to be on the effect the relevant external actor/state had on the exercise of popular constituent power. To aid in this assessment, a distinction needs to be made between cases of external exercise of and external influence on constituent power. If the intervention of an external actor amounts to an exercise of constituent power, the democratic legitimacy of the process will be compromised. If, however, an external actor simply influences a popular exercise of constituent power, the process's democratic legitimacy will be unharmed and may even be enhanced.

81 Agné, above n 64, at 858 
There is no clear point at which external influence becomes an external exercise of constituent power. The complexity of constitution-making means that it is more likely to fall somewhere along a spectrum. ${ }^{82}$ Dann and Al'Ali identify three categories of external influence along this spectrum: marginal, partial and total. "Marginal influence" occurs when an external actor is involved but control over the process and substance remains in the hands of the people (for example, when a state seeks constitutional advice). In such instances, the popular constituent power could easily be recognised as having been influenced. Conversely, "total influence" occurs when an external actor takes control of the constitution-making process to such a degree that the people's constituent power is completely displaced. In such cases, the effect is a clear external exercise of constituent power or imposition. In the grey area between these poles is the "partial influence" of constituent power. In such cases, "the pouvoir constituant is neither entirely surrendered nor is it kept entirely intact. Instead, control over the constitutional process is shared". ${ }^{83}$ In these cases, it becomes less clear whether constituent power is exercised by an external actor or power, or simply influenced.

Adopting a more nuanced understanding of constituent power raises a fresh series of critical questions. To identify when external influence becomes an external exercise of constituent power, it is necessary to have some idea of what actually counts as an exercise of constituent power. There is a need to ask: what aspects of the process must be in the hands of the people to allow a conclusion that there was an exercise of popular constituent power? Or as questioned by Preuss: "what conditions must be fulfilled in order that it is 'the people' which we can recognise as the true author of the constitution and consequently, the source of its normative validity" ${ }^{84}$

It is helpful at this stage to return to Schmitt's concept of the "fundamental political decisions" of a constitution. For Schmitt: 85

The political decision reached regarding the type and form of state existence, which constitutes the substance of the constitution, is valid ... because the subject of the constitution-making power determines the type and form of this existence.

Because in a democracy the subject of the constitution-making power is the people, it is they who must determine the fundamental political decisions of their constitution for it to be democratically legitimate. A popular exercise of constituent power requires that the people determine the fundamental political decisions. In cases where an external actor determines one or several such decisions, an external exercise of constituent power can be said to have occurred.

82 Dann and Al-Ali, above n 67, at 428.

83 At 430 .

84 Ulrich Preuss "The Exercise of Constituent Power in Central and Eastern Europe" in Martin Loughlin and Neil Walker The Paradox of Constitutionalism (Oxford University Press, Oxford, 2007) 211 at 212.

85 Schmitt, above n 51, at 136 
Difficulty may arise, however, when determining who ultimately determined a constitution's fundamental political decisions. To assist in this regard, the literature on constitution-making identifies certain procedures and mechanisms that are seen as necessary for the constitution to be considered a product of a popular exercise of constituent power (ie democratically legitimate). ${ }^{86}$ Though academic views diverge as to the finer details, there is general consensus that democratic constitution-making requires a desire "from below" to undergo constitutional change, ${ }^{87}$ open and participative constitutional deliberations led by an elected constitution-making body, and ratification by the people (state citizens) of the final proposed constitution. Where these procedures are followed, it becomes possible to conclude that the fundamental political decisions encapsulated in the final constitution reflect the political will of the people. Conversely, their absence leaves open the possibility of an external exercise of constituent power.

If it is found that external influence did not amount to an exercise of constituent power but rather just an influence, the effect this influence had on the process overall still requires attention. Given that constitution-making ought to be a national exercise (and the risks associated with external actors exercising constituent power), unless external influence enhances a popular exercise of constituent power it ought to be discouraged.

Agné explains how external intervention in constitution-making can "enhance internal abilities". By defining autonomy as the "capacity of individuals to reflect on, and to choose among, alternative and widely different courses of action in their individual as well as collective life", 88 Agné argues that an external actor enhances their constituent power by contributing to the range of constitutional alternatives available to the people. ${ }^{89}$ Take for example the external adviser who offers alternative political models that accord with the people's desired political order. The adviser's input can be seen as having enhanced the people's autonomy by making available to them a greater range of constitutional options they may not otherwise have considered. In turn, the people are better able to contribute to the making of the constitution's fundamental political decisions, and thus to exercise their constituent power.

Finally, an assessment of the democratic legitimacy of the constitution should not be limited to the initial constitution-making episode. Even under a constitution initially created by an external exercise of constituent power, a people could reclaim its constituent power by amending the

86 See generally Ginsburg, Elkins and Blount, above n 79; Andrew Arato "Forms of Constitution-making and Theories of Democracy" (1995) 17 Cardozo L Rev 191; Joel Colón-Ríos "Notes on Democracy and Constitution-Making" (2011) 9 NZJPIL 17; Elster, above n 59; and Jonathan Wheatley and Fernando Mendez (eds) Patterns of Constitutional Design: The Role of Citizens and Elites in Constiution-Making (Ashgate Publishing, England, 2013).

87 Colón-Ríos, above n 86, at 36.

88 Agné, above n 64, at 856.

89 At 860. 
constitution (or by deciding not to amend it while having the power to do so). An analysis of democratic legitimacy in constitution-making should therefore extend to whether the people have subsequently "become authors of their constitution, even if they were not so when the constitution was originally created". ${ }^{90}$ This is based on the understanding that the "constitution-making power is not thereby expended and eliminated, because it was exercised once". 91

There are several benefits to accepting a more nuanced conception of popular constituent power that underpins the analytical framework advanced above. There is the obvious advantage that it is more responsive to reality. By recognising that external influence is not necessarily democratically attenuating, a more insightful analysis of the external influence and the effect that it had on the process becomes possible. It further allows for recognition of the value that can be added to the constitution-making process by involving outsiders.

There are, however, negatives associated with rejecting a strict conception of popular constituent power. By maintaining that constituent power must be exercised by the people to be democratically legitimate, the approach is more restrictive than that advanced by the likes of Oklopcic. In fact, it is true that on this approach it is likely that most external interventions will be considered damaging to the democratic legitimacy of the constitution-making process. This simply reflects the reality that democracy requires that people ought to have the power to determine the constitutional regime under which they live.

A more compelling critique is that a flexible conception introduces ambiguity to the role of external actors in the constitution-making process. A clear-cut approach like that provided for by a strict conception of popular constituent power makes it easier to identify inappropriate (democratically damaging) input (ie any external influence). The practical consequence of such an approach is that it sends a stronger message to outsiders not to get involved in what should be a national and citizen-driven exercise. Though this is a valid concern, strict rules are incompatible with the fundamentally political exercise that is constitution-making.

\section{ANALYSING THE CASE STUDIES}

Based on the discussion in the preceding section, the analytical framework on which the case studies will be assessed involves asking two key questions in the alternative. First, were the people of the Cook Islands and Niue responsible for the fundamental political decisions in the respective constitution-making processes? If so, did New Zealand's role in the processes enhance the people's capacity to make those decisions, and thus their constituent power? If not, have the people subsequently reclaimed their constituent power?

90 Joel Colón-Ríos "The Legitimacy of the Juridical: Constituent Power, Democracy, and the Limits of Constitutional Reform" (2010) 48 Osgoode Hall LJ 199 at 201.

91 Schmitt, above n 51, at 125 . 
The circumstances surrounding the constitutional experiences of the Cook Islands and Niue raise issues of partial influence. New Zealand did not unilaterally write the respective Constitutions, nor did it remain completely absent from the processes. It did however recognise a role for itself in the constitution-making process of its colonies. Alison Quentin-Baxter, assistant to the NIA's constitutional adviser, explains: ${ }^{92}$

As administering authority, the New Zealand Government saw itself as having a responsibility and a right to contribute to the decision-making. The people of Niue wished to remain New Zealand citizens, and were seeking a relationship of free association with New Zealand. As a term of this relationship, New Zealand would have a continuing responsibility to provide necessary economic and administrative assistance to Niue.

Because of the dependent nature of the relationship and the ongoing political ties sought, there was considerable scope for New Zealand to wield significant influence, directly or indirectly, over the constitutional deliberations of the Cook Islands and Niue.

To ascertain what effect New Zealand did have, it is necessary to return to the constitutionmaking processes in the Cook Islands and Niue.

\section{A Cook Islands}

The Cook Islands was generally enthusiastic about the prospect of self-government. There was certainly concern regarding what self-government meant for the state's future relationship with New Zealand. However, following assurances that assistance would continue, the people embraced constitutional change much more readily than Niue. Somewhat paradoxically, this resulted in the people of the Cook Islands having less control over the constitution-making process and its corresponding fundamental political decisions. The substantive and procedural limitations placed on the constitutional deliberations by accepting the New Zealand Government's timetable for selfgovernment, coupled with lack of public participation throughout, led to outsiders being able to take the lead in the process and to ultimately determine key fundamental political decisions.

Having instigated the constitution-making process in the Cook Islands, New Zealand proceeded to exert significant influence throughout the process by providing what became the framework for constitutional development and deliberations. After the CILA passed a resolution requesting "that the New Zealand Government proceed with its plan for giving the Cook Islands the fullest (possible degree of) internal self-government", ${ }^{93}$ New Zealand prepared a timetable "for future political development". ${ }^{94}$ The timetable set out steps for a gradual handover of power, accounting for a

92 Quentin-Baxter, above $\mathrm{n} 41$, at 248 .

93 Cook Islands Legislative Assembly, above n 22.

94 Cook Islands Legislative Assembly, above n 15, at 3. 
withdrawal of the official members in the Legislative Assembly (1964), the establishment of a Cabinet (1964), the appointment of the Resident Commissioner as constitutional Head of State (1965), the establishment of an Executive Council (1965) and a final increase in legislative powers (1965).

By choosing to base the CILA constitutional deliberations on this timetable, the issues discussed ultimately revolved around these proposals. ${ }^{95}$ The proposals were only intended to guide discussion, but given that the advisers only had five days to discuss the constitution with the CILA, there was not sufficient time to fully explore alternatives. In addition, the advisers tended to lead the discussions. For each step, they described the proposal, the possible alternatives and often, at this point, their own view on the matter. The advisers undoubtedly sought to advance the Cook Islanders' interests by offering their considered opinion. However, in addition to the (somewhat unavoidable) limitations stemming from an adviser's background, ${ }^{96}$ their lack of interaction with the local people significantly limited the degree to which their advice can be seen as responsive to the political will of the people.

Throughout the constitution-making process, there was little opportunity for the people of the Cook Islands to be directly involved. The geography of the Cook Islands made this a particular challenge - the distance between the 15 islands is immense and transport at the time was infrequent. Being aware of these constraints, efforts were made by the Cook Islands Government to ensure that the Islanders were informed of the constitutional developments. The discussions in the CILA were recorded and subsequently broadcast on the radio and reported in considerable detail in the Cook Islands News. ${ }^{97}$ The problem however lay in the lack of opportunity for the people to communicate their views back to the constitution-making body. As conceded by the Resident Commissioner at the time, at no point were the villagers invited to make submissions on the advisers' report or any later draft constitution. ${ }^{98}$ The proposed Constitution was considered by a Select Committee in Wellington (at which no interpreters were present). ${ }^{99}$ Further, though a delegation of CILA Members travelled

95 Cook Islands Legislative Assembly Minutes from the Cook Islands Legislative Assembly (23 August 1963).

96 As explained by Alison Quentin-Baxter, "a constitutional adviser's proposals are likely to be circumscribed by his or her own background, knowledge and personal philosophy": see Quentin-Baxter, above n 41, at 273

97 Aikman, Davidson and Wright, above n 24, at 520. The report noted that as a result of the Government's efforts, "a significant section of the people throughout the Cook Islands became acquainted with the various problems under consideration".

98 Mr Rata (Select Committee member): "There was no provision for the Assembly to hear opinions on that Report?" Mr Dare (Resident Commissioner): "We have never advertised that anybody could come along and make submissions to the Assembly or any special committee." See Island Territories Committee, above n 27 , at 89 .

99 David Stone "Self-Determination in the Cook Islands: A Reply" (1965) 74(3) Journal of the Polynesian Society 360 at 364. 
to attend the Committee hearing, the advisers answered many of the questions put to the delegates because of their "technical" nature. ${ }^{100}$

Finally, despite the New Zealand Government having indicated in 1962 that once a plan for selfgovernment had been prepared, "a plebiscite would be arranged to see if the plan was acceptable to the people as a whole", ${ }^{101}$ the Constitution was never subject to a popular referendum. When asked about this in the New Zealand Parliament, the Prime Minister explained that, while the Government had no objection to a referendum, the people of the Cook Islands had not requested one. ${ }^{102}$ The problem with this approach is that there was not much opportunity for the people to ask.

To satisfy the UN requirement that associated status was "the result of a free and voluntary choice", ${ }^{103}$ a general election was arranged to be held before the Constitution came into force in place of a referendum. ${ }^{104}$ The idea was that, as the Constitution was to be a central election issue, electors would have the chance to vote for candidates according to whether they supported the Constitution or not. Whether the election can be said to have had an effect similar to that of a referendum is however far from clear. The candidates who campaigned in support of a different variation of the proposed Constitution were defeated, but this was only seven out of the $66 .{ }^{105}$ Furthermore, being a general election, the Constitution was not the only issue informing voters' choices. ${ }^{106}$

It is clear from the minutes of CILA's constitutional deliberations that certain fundamental political decisions were made by its Members. That the Cook Islands was to operate as a democracy

100 This prompted Sir Leslie Munro (member of the Select Committee) to ask about the meaning in the constitution's clause referring to the making of laws having extra-territorial operation. Professor Aikman (adviser) replied, "With respect, I wonder whether that is a fair question. I doubt if many members of this committee really understand what is meant by this highly technical question of extra-territorial jurisdiction." To this, Sir Leslie Munro explained: "I asked it as a very general question because I want to know whether these good and important people have an idea of what the Constitution Bill really means. I know perfectly well that Mr Dare, Professor Aikman and Mr Wright can explain this Bill." Island Territories Committee, above $\mathrm{n} 27$, at 17

101 Gotz, above n 13, at 106 .

102 (21 October 1964) 340 NZPD 2836.

103 Principles which should guide members in determining whether or not an obligation exists to transmit the information called for under Article 73e of the Charter, above n 12, Annex, Principle VII(a).

104 Island Territories Committee, above n 27, at 92-93. See also David J Stone "Self-Rule in the Cook Islands: The Government and Politics of a New Micro-State" (PhD Thesis, Australian National University, 1971).

105 Stone, above $\mathrm{n} 99$, at 368 .

106 The UN subcommittee was, however, of the opinion that the general election (to be observed by the UN) and the subsequent decision in the CILA, would constitute an "identifiable act of self-determination". United Nations Report of Sub-Committee II of the Special Committee of 24 (1964) at 9. 
with the Queen as the Head of State was firmly supported in the discussions. ${ }^{107}$ Other decisions on proposals that the CILA were less familiar with, however, can be less clearly attributed to the Members owing to the advisers' approach. In discussions relating to the functioning of Cabinet government, what the advisers expressed "was the best way", or the option "they ought to take", were eventually agreed upon by the members. ${ }^{108}$

Further, it is evident that the initial decision to become a self-governing state in free association with New Zealand was clearly not fully determined by the CILA. When the CILA was first presented with four options for constitutional change in 1962, the decision to become self-governing in free association with New Zealand was swiftly made by the Members of the Assembly, without consulting their constituents. ${ }^{109}$ The CILA was fully elected, and on that basis the people could be seen as having made this decision indirectly. As became subsequently apparent however, the Members themselves did not fully understand what they were voting in favour of. When the advisers arrived at the CILA the following year, one member sought clarification as to what internal self-government actually meant. Joining in on this question, another member noted: "It is true the people do not truly understand the four doors [options] - there is a need for explanation."110

The procedural and substantive constraints on the constitutional deliberations in the Cook Islands, coupled with the lack of public participation at every stage of the process, resulted in fundamental political decisions being overly influenced by New Zealand officials and advisers. As a result, New Zealand can be seen as having exercised a degree of constituent power in the Cook Islands at the expense of the people.

Before concluding on the democratic legitimacy of the constitution-making processes in the Cook Islands, it is necessary to consider its constitutional experience following the creation of the Constitution. Before the Constitution even entered into force, the CILA requested that the New Zealand Parliament make several amendments. The impetus for the hasty request was that the to-be Premier, Mr Albert Henry, was excluded from running for election due to the candidate rules. Along with amending the candidature rules, the amendment also provided for the creation of a consultative

107 Cook Islands Legislative Assembly Minutes from the Cook Islands Legislative Assembly (29 August 1963).

108 For example, the advisers recommended adopting the Cabinet system instead of the Committee system, having the Premier select Cabinet members instead of having a voting system, and having a smaller Cabinet (five members) instead of the preferred larger membership. In each instance, the CILA went on to agree with the advisers. Even in the instance that they did not (in relation to the number of Cabinet members), the advisers' view was that which was encapsulated in the report. See Cook Islands Legislative Assembly Minutes of the Cook Islands Legislative Assembly (19, 26 and 27 August 1963).

109 Angus Ross (ed) New Zealand's Record in the Pacific Islands in the Twentieth Century (Longman Paul Ltd, Auckland, 1969) at 108.

110 Cook Islands Legislative Assembly Report of the Cook Islands Legislative Assembly (23 August 1963) per Hon T Roi. 
body of traditional leaders - the "House of Arikis", which had been largely excluded from the initial Constitution. ${ }^{111}$

Since the passing into force of the Cook Islands Constitution, it has been amended 30 times, and "now differs markedly from the version enacted in 1965."112 To amend a provision of the Constitution, the amendment must receive support from two-thirds of the total membership of the CILA in two votes taken at least ninety days apart. ${ }^{113}$ For those provisions that are considered the "core" provisions of the Constitution, ${ }^{114}$ the amendment must also be submitted to a poll and supported by no less than two-thirds of the voting population. ${ }^{115}$

Amendments to the Cook Islands Constitution have included those to remove the power of the New Zealand Parliament to make laws for the Cook Islands altogether, ${ }^{116}$ to patriate the court system, ${ }^{117}$ to provide for a bill of rights, ${ }^{118}$ and to give recognition to custom. ${ }^{119}$ Several of these amendments were passed explicitly to convince the international community that the Cook Islands was a state at international law; ${ }^{120}$ to remove what the Minister of Justice at the time described as perceived "vestiges of the Colonial System". ${ }^{21}$ The result has been a Constitution with a real "separate identity". ${ }^{122}$ On this basis, it must be concluded that at least some of the "lost" constituent power has been regained as the people have reasserted their constituent power.

\section{B Niue}

Niue's constitutional experience is a "rags to riches" tale - starting out poorly, it eventually proved to be an enriching experience for the Niuean people.

111 Constitution of the Cook Islands, art 8.

112 Laws of New Zealand "Pacific States and Territories: Cook Islands" (online ed) at [8].

113 Article 41(1)

114 Cook Islands Constitution Act 1964, ss 2-6 and arts 2 and 41 of the Constitution.

115 Article 41(2).

116 Cook Islands Constitution (Amendment) Act 1980, s 5.

117 Section 7.

118 Section 8 .

119 Cook Islands Constitution (Amendment) Act 1994, s 7.

120 Laws of New Zealand, above n 112, at [15].

121 Press statement made by the Cook Islands Minister of Justice at the time of introduction of the Cook Islands Constitution (Amendment) Bill 1980. As quoted in CC Aikman "Constitutional Developments in the Cook Islands" in Peter Sack (ed) Pacific Constitutions (ANU Printing, Canberra, 1982) 87 at 89.

122 Aikman, above n 121, at 89. 
At the outset, New Zealand has been accused of "resort[ing] to an approach which strongly implied desperation in dealing with the Niue situation". ${ }^{123}$ As was the case in the Cook Islands, New Zealand wanted Niue to rapidly shift from a colony to a fully self-governing state. Niue however did not desire any such rapid change. By initially overlooking the concerns of the Niuean people, New Zealand risked making decisions on Niue's behalf and displacing the people's constituent power.

Before New Zealand presented the CILA and the NIA with four options for constitutional change, the New Zealand Cabinet had already approved a timetable towards self-government. ${ }^{124}$ "Whether the Cook Islands and Niue Assemblies were implicitly aware that these four alternatives did not offer any real choice did not seem to concern New Zealand", explains Chapman. ${ }^{125}$ New Zealand's unilateral approach to dealing with Niue, however, continued. In 1962, after the NIA had cautiously accepted self-government in principle, New Zealand proceeded to present a timetable for Niue's shift to self-government to the UN, before having discussed any such timetable with the NIA.

Behind New Zealand's hasty approach was clear pressure from the UN which was committed to "bringing to a speedy and unconditional end colonialism in all its forms and manifestations". ${ }^{26}$ Though purporting to champion the Niuean people's rights, the people of Niue did not appreciate the UN's doctrinaire approach. They felt like the UN, an organisation of which they knew little, was forcing Niue apart from New Zealand and trying to push them into making a decision that vitally concerned them. One member of the public said: ${ }^{127}$

We have been told some time ago that self-government was first suggested by New Zealand in connection with the wish of the United Nations. It is the wish of New Zealand or the United Nations, but they do not know much about Niue, what Niue can produce, how well off Niue is or how badly off financially.

Despite the pressure placed on Niue to decolonise, the NIA refused to be rushed into selfgovernment. Owing to its fear of change, Niue resisted the pressure from New Zealand and in doing so took its constitutional development into its own hands. After consulting the people, ${ }^{128}$ the NIA

123 Chapman, above n 10, at 17.

124 Confidential Telegram No 276 from Mr McEwan (20 June 1962). Confirmed in a letter to McEwen (Resident Commissioner of Niue) regarding the "Future Policy in New Zealand's Island Territories" (22 June 1962).

125 Chapman, above n 10, at 12 .

126 Declaration on the Granting of Independence to Colonial Countries and Peoples, above n 7.

127 Niue Island Legislative Assembly Minutes from the Niue Island Legislative Assembly (21 January 1965) (with Aikman and McEwen) at 5.

128 Niue Island Legislative Assembly Minutes from the Niue Island Legislative Assembly (13-14 August 1963). The Ministers' reports to the NIA were that the people's views on self-government were very mixed. 
rejected the timetable offered by New Zealand (that would have seen it attain self-government by 1966), and instead passed a resolution stating that the "people should be asked by secret ballot" to determine the pace of constitutional developments. ${ }^{129}$ The NIA then went on to inform advisers twice that Niue was not ready for constitutional change. Eventually, Niue took responsibility for creating its own timetable - informed by consultation with the local people - according to which it eventually attained self-government. Once the constitution was drafted, copies were sent to each household before the people were asked to vote on it in a UN observed referendum. As reported in the UN Report on the Referendum, "the Mission gained the impression that everything possible had been done to associate the people of Niue with the issues involved and with the provisions of the draft constitution". 130

Public participation did not render Niue immune from the influence of New Zealand officials and advisers, but the potentially undemocratic effect of that influence was significantly attenuated because of it. By seeking the people's opinion on constitutional change, there was an unspoken obligation on the New Zealand officials and advisers alike to listen to and be guided by those opinions. During his visits, Professor Quentin-Baxter met with members of the NIA, the Executive Committee, the Niue Development Board, representative groups from the Public Service, the Resident Commissioner and locals through "well-attended village meetings in all parts of the island". ${ }^{131}$ His reports and subsequent constitutional recommendations were guided by this extensive consultation. ${ }^{132}$ As the NIA's adviser, he was clear that his "first responsibility is to ensure that every decision does reflect [the Niuean people's] will, arrived at without any outside constraint, and after they have understood the choices and implications". ${ }^{133}$

New Zealand attempted to push Niue along and pre-empt decisions that ultimately were Niue's to make. Assisted by its adviser however, Niue managed to resist that pressure to a considerable extent and avoid an otherwise likely external exercise of constituent power. As it turned out, it was Niue that retained primary control over its fundamental political decisions. As in the Cook Islands, the people were always clear that it would function as a democracy with the Queen in Right of New Zealand as its Head of State. Unlike in the Cook Islands however, the decision to become self-

129 Niue Island Legislative Assembly Minutes from the Niue Island Legislative Assembly (9 October 1963).

130 Report of the United Nations Special Mission to Observe the Act of Self-Determination in Niue A/9623/Add 5 (Part V) Chap XXII (1974) at 25[81].

131 At 5[2].

132 For example, responding to the persistent concerns expressed to him by the people regarding Niue's economic future, Professor Quentin-Baxter recommended the inclusion of a section in the Niue Constitution Act that New Zealand would continue to provide "necessary economic and administrative assistance to Niue" (s 7 of the Niue Constitution Act 1974).

133 RQ Quentin-Baxter, Telegram (20 June 1974) from Geneva to Wellington, as quoted in Quentin-Baxter, above $n$ 41, at 273 . 
governing was one made by the people of Niue, on their own terms, when they were ready. As Hon R Rex made clear to the UN Visiting Mission: "it is self-government we want, we will decide when that will be - not when mother New Zealand says and certainly not when the United Nations says". 134

It could be said that there is intrinsic value in encouraging a country to decolonise and take control of its own affairs. Indeed, under certain conditions such encouragement could be seen as enhancing the people's constituent power by offering them a broader range of constitutional options. New Zealand's approach however, at least at the outset, was informed by its own interests to get itself off "the colonial hook" and cannot be said to have had this effect. The pressure felt by the Niuean people is clear in Professor Quentin-Baxter's first report. Explaining why many Niuean people were concerned about constitutional change, he noted that there: ${ }^{135}$

... lay a fear that the fixed timetable for constitutional development had never really been withdrawn. It had, they felt, continued to tick away while the people were wrapped in a sense of false security - until now they found themselves unwillingly on the very brink of self-determination.

Allowing the status quo to continue while expecting that the desired constitutional change will inevitably occur does not amount to enhancing the Niuean people's constitutional options - it rather limits them. While New Zealand's influence in the constitution-making process in Niue therefore may not have amounted to an exercise of constituent power, it did not have the positive effect of enhancing a popular exercise.

Finally, it is interesting to note that Niue's Constitution has only ever been amended once. ${ }^{136}$ The Constitution's stringent amendment procedure is undoubtedly responsible for its lack of amendments. Every proposed amendment, along with attaining the requisite parliamentary majority, ${ }^{137}$ must be submitted to a popular referendum. For most amendments a simple majority will suffice. For certain provisions however, including those relating to Niue's political relationship with New Zealand, ${ }^{138}$ a super majority of two thirds support for the amendment is required. This

134 Report of the United Nations Visiting Mission to Niue, 1972 A/AC 109/L 810/Rev 1, Annex 2 (Statement by Leader of Government, 21 June 1972).

135 Quentin-Baxter, above n 39, at 6[8].

136 Niue Constitution Amendment Act 1992. This was an omnibus bill comprising three amendments for which voters could vote in favour of all or none. Amendments included those to patriate the court system and make the specialist Lands Courts a division of the High Court (s 4), change the qualifications for electors and candidates (s 2), and repeal the special provisions for proposed legislation relating to criminal law or status of persons (s 3)

137 The proposed amendment must have the support of two thirds of the NIA members evidenced in two votes taken at least 13 weeks apart. Niue Constitution Act 1974, art 35.

138 Sections 2-9, and arts 1 and 69. 
rigorous amendment process has been credited with contributing to the Constitution's stability, but it raises real concerns that the people's constituent power is being constrained. To be clear, it was at the insistence of the local people that there be significant barriers in place to prevent certain provisions of the Constitution being changed. The people did not want the Constitution, and in particular those provisions relating to Niue's on-going relationship with New Zealand, to be subject to the whim of politicians. ${ }^{139}$ There is no denying, however, that the amendment procedures of the Niue Constitution pose a significant barrier to present expressions of popular constituent power.

\section{A BETTER APPROACH: A TWO-STAGE MODEL}

\section{A Background}

Constitution-making ought to be a national exercise - one in which the people come together and map out their future political order. For a range of reasons however, ${ }^{140}$ an external state will often play a key role in the future political order of small, dependent non-self-governing island states. Any model for constitution-making for such island states would best recognise this fact and be modelled accordingly.

This part will propose a model of constitution-making that expressly recognises a role for an external state (or several). It is designed with the remaining non-self-governing island states in mind: American Samoa, Guam, Pitcairn, French Polynesia, New Caledonia and Tokelau in the Pacific, and Anguilla, Bermuda, British Virgin Islands, US Virgin Islands, Cayman Islands, Montserrat, Falkland Islands (Malvinas), Turks and Caicos Islands and St Helena in the Caribbean and Atlantic. The model would apply in the instance that these island states sought to shift towards a formal self-governing status of some description as was the case in the Cook Islands and Niue. ${ }^{141}$ The model proceeds on the view, as defended in the previous parts of this article, that it is possible to have an exercise of popular constituent power while involving an external state in the constitution-making process. The key object of the proposed model is to provide an avenue for the external state to participate in or contribute to the process while ensuring that this does not impinge

139 Quentin-Baxter, above n 40, at 583.

140 There are several reasons why a non-self-governing territory would choose some form of associated statehood over full independence. An associated political status normally entails significant administrative and economic benefits, social welfare assistance, higher quality health and education assistance, natural disaster relief, and the provision of costly external defence. Further, there are significant employment and material benefits that come with retaining shared citizenship. Overall, the empirical data has shown that island states that are not fully independent enjoy a higher living standard than independent island states. See generally G Bertram "On the Convergence of Small Island Economies with their Metropolitan Powers" (2004) 32 World Development 343 at 353; and Baldacchino, above n 4, at 193.

141 While the non-self-governing island states share characteristics, the particular features of each island state would need to be carefully considered. 
on the people's exercise of constituent power. It is ultimately aimed at enhancing the democratic legitimacy of external influence in constitution-making.

The constitutional experience of Tokelau, New Zealand's last remaining dependent territory, ${ }^{142}$ provides in part the inspiration for the proposed model, and therefore will be discussed in brief.

In 2006 and 2007, the people of Tokelau were asked to vote in referenda to determine whether Tokelau would become self-governing in free association with New Zealand. Though the requisite proportion of votes to decolonise was not met, the pre-referendum processes offer insight into a unique approach to constitution-making for small dependent island states seeking to decolonise.

The referenda to decide on the future status of Tokelau proceeded on the basis of two documents: the draft Treaty of Free Association and the draft Constitution. These documents were to provide the legal framework for Tokelau if it were to become self-governing. The documents were related but designed to serve two distinct purposes: the draft Treaty outlined the terms of the relationship of free association between the two states, while the draft Constitution set the rules for Tokelau's self-government. In light of the distinct functions, the documents were the products of distinct processes: the Treaty was a "collaborative effort between Tokelau and New Zealand", while the draft Constitution was a "Tokelauan effort throughout". ${ }^{143}$

The initiative to record Tokelau's prospective relationship with New Zealand in a treaty was proposed by the constitutional adviser, Professor Tony Angelo. The people of Tokelau were concerned that economic and administrative support from New Zealand would decrease if selfgovernment was attained, as had been observed in the Cook Islands and Niue. It was considered that, by binding the parties at the international level, stronger protection would be afforded to the relationship while also placing the parties on an equal footing in the instance that obligations were breached or sought to be modified. ${ }^{144}$

For Tokelau, the result of the pre-referendum effort was a fully autochthonous draft Constitution. ${ }^{145}$ Its substance was an articulation of a political order that had emerged, for the most

142 The Tokelau Act 1948 established Tokelau as "part of New Zealand". Having rejected self-government, Tokelau remains a dependent territory of New Zealand. It is still on the UN list of non-self-governing territories. See Andrew Townend "Tokelau's 2006 Referendum on Self-Government" (2007) 5 NZJPIL 127; and AH Angelo "The Constitution of Tokelau" (2009) 15 Revue Juridique Polynésienne 181.

143 Townend, above n 142, at 144 .

144 Compare this position with that of the Cook Islands and Niue. New Zealand can alter the terms of the relationship by amending the relevant Acts by a simple majority in the New Zealand Parliament. The Cook Islands and Niue can only change the terms of the relationship according to the amendment provisions in the respective Constitutions - which, for Niue especially, presents a significant hurdle.

145 Had the referenda been successful, the draft Constitution would have become the supreme law of Tokelau. As this did not happen, it remains in place as a consolidation of key constitutional rules already in force. See Angelo, above n 142, at 182 . 
part, internally, and reflected a "coral-up" approach. To come into force, the Constitution was "to spring forth", not by a positive act by the New Zealand Parliament, but by its withdrawal. ${ }^{146}$ At the same time, by virtue of the draft Treaty, Tokelau was to maintain its New Zealand citizenship and was assured ongoing economic and administrative support "to maintain and improve the quality of life of the people of Tokelau". ${ }^{147}$

Looking back at the constitutional experiences of the Cook Islands and Niue, it is clear that there were problems stemming from tying the decision regarding the states' political status (and hence the future relationship with New Zealand) with the constitution-making process. ${ }^{148}$ The uncertainty regarding New Zealand's intentions throughout consistently overshadowed the constitutional deliberations, diverting attention away from matters of constitutional design. ${ }^{149}$ Further, by not clearly delineating at what stage New Zealand's involvement was appropriate, its influence permeated the entirety of the constitution-making process. In both cases, New Zealand's role failed to enhance the constituent power of the people, and in the case of the Cook Islands, it ultimately led to an external exercise of constituent power.

The approach taken in Tokelau largely avoided the issues faced in the Cook Islands and Niue by procedurally separating out the processes pertaining to the state's future political status and constitution. Building on Tokelau's experience, the proposed model therefore consists of two stages. To reduce the risk of undemocratic external influence in the constitution-making process to the greatest extent possible, the model will further propose temporally separating the processes regarding a non-self-governing state's political status and constitutional regime, with a recognised interim period in between. ${ }^{150}$

146 Townend, above n 142, at 149.

147 Draft Treaty of Free Association between New Zealand and Tokelau, art 4.

148 Interestingly, there is an implicit distinction between the two stages in the Constitutions. As explained by Professor Angelo, "[t]he physical and terminological distinction in the Constitution of Niue between its sections and its articles ... reflects two sides of the coin: the relationship of free association with New Zealand and the self-governing state." AH Angelo "The Niue Constitution" (2009) 15 Revue Juridique Polynésienne 157 at 159 .

149 This was picked up by Sir Leslie Munro during the Select Committee. He noted: "When I was there about three months ago I do not think anybody approached me and spoke to me about this constitution. All I had were questions as to whether the people would have the right to come to New Zealand whenever they liked. Do you agree that this is a pretty common approach?" Mr Dare (Resident Commissioner): "Yes, I think so." See Island Territories Committee, above n 27, at 82.

150 This model draws on Arato's two-stage "democratic constitution-making" model, but departs from it in several key ways. Arato perceives two instances that play a fundamental role in the drafting process: an "instance that drafts the interim constitution, typically a round table of major political forces, and an instance that drafts the final document, always a freely elected body...". The former instance creates constitution-making rules that are binding on the latter. For post-conflict states, this process provides promise, but it is rejected for application in the context of small dependent states. Procedurally, it is over 


\section{B The Proposed Model}

The first stage of the proposed model would centre on determining the future political status of the non-self-governing state. As any proposed change in the state's political status would likely involve ongoing relations with an external state (for example, in the form of a relationship of free association), the external state would enjoy a recognised role at this stage. Representatives of both states would convene to negotiate the terms of the states' future relationship and the ongoing obligations on each. Though this stage may take the form of negotiations between political powers, there is nothing preventing a high level of public consultation throughout. Some aspects of the negotiations may indeed have to be closed, ${ }^{151}$ but to ensure that the respective parties are fully aware of the relevant considerations and interests at stake, the public should be informed of the issues and given a forum through which to communicate their views.

Once the parties have agreed on the nature and form of the states' future relationship, the outcome of the negotiations would be encapsulated in a treaty. ${ }^{152}$ As proposed by Alison QuentinBaxter in her "sustained autonomy" model, the international community would thereby become "the guarantor of the continuation of the necessary support for small autonomous islands". ${ }^{153}$ It would be on the basis of this treaty that the people would vote in a referendum to determine their future political status. If rejected, no change would occur - the status quo would continue. ${ }^{154}$ If the proposed change is accepted, however, the treaty would subsequently be signed by the respective parties and enter into force. Regardless of what they choose, the people in the island-state would retain the power to change their political status at any point in the future. ${ }^{155}$

complicated for such small jurisdictions, and substantively, it clashes with the position defended in this article that constituent power should not be limited or constrained. The general thrust of Arato's recognition of "the importance of state building in the first stage and regime creation dominating in the second stage" is picked up in the proposed model. See Andrew Arato "Redeeming the Still Redeemable: Post Sovereign Constitution-making" (2009) 22 Int J Polit Cult Soc 427.

151 As is the case with constitution-making. See Elster, above n 59, at 388 .

152 Alison Quentin-Baxter "Sustained Autonomy: An Alternative Political Status for Small Islands" (1994) 24 VUWLR 1 at 17. In her model, the external state would enter into a treaty with an international organisation, though it seems more appropriate that the primary state itself be a party to the treaty as was to be the case in Tokelau.

153 At 17.

154 For an argument in favour of the UN General Assembly recognising the status quo see Elisabeth Perham "A Solution for the Third International Decade for the Eradication of Colonialism: A 'Fourth' Option to Obviate the Need for a Fourth Decade?" (LLB (Hons) Dissertation, Victoria University of Wellington, 2013) at 32.

155 This is required under the General Assembly Resolution 1541, Principle VII(a). See Principles which should guide members in determining whether or not an obligation exists to transmit the information called for under Article 73e of the Charter, above n 12. 
A successful referendum, in which the requisite proportion of people voted in favour of the proposed new political status, would constitute an internationally recognised act of selfdetermination. The former territory's status, under which its international personality was severely limited, ${ }^{156}$ would come to an end. This is made clear in Resolution 2625 of the General Assembly, which states: ${ }^{157}$

The territory of a colony or other Non-Self-Governing Territory has under the Charter, a status separate and distinct from the territory of the State administering it; and such separate and distinct status under the Charter shall exist until the people of the colony or Non-Self-Governing Territory have exercised their right of self-determination in accordance with the Charter, and particularly its purposes and principles.

By exercising its right to self-determination in a fair and free referendum, the newly selfgoverning state would attain the capacity to enter into treaties, such as that between it and the external state. Article 6 of the Vienna Convention on the Law of Treaties declares that "every State" has the capacity to conclude treaties. ${ }^{158}$ The international statehood of associated states has not always been recognised. When the Cook Islands and Niue became self-governing, it was not considered possible for them to enter into international treaties. As evidenced by the range of multilateral and bilateral treaties that the Cook Islands and Niue have entered into since decolonisation, ${ }^{159}$ it is clear that it is now possible for associated states to be recognised as "states"

156 For example, although Tokelau is substantially self-governing in practice, as a dependent territory of New Zealand, it does not have a separate international legal personality. For the most part, the New Zealand Government undertakes any treaty-making in respect of Tokelau on the basis of consultation with the Government of Tokelau. See Ministry of Foreign Affairs "International Treaty Making: Guidance for government agencies on practice and procedures for concluding international treaties and arrangements" (September 2012) <http://www.mfat.govt.nz>. For comments of the Special Rapporteur on the treatymaking capacity of protectorates and other dependent States, see generally Sir Humphrey Waldock "First Report on the Law of Treaties" in Yearbook of the International Law Commission [1962] vol 2 YILC at 37.

157 Declaration on Principles of International Law Concerning Friendly Relations and Cooperation among States in accordance with the Charter of the United Nations GA Res 2625, XXV A/RES/2625 (1970) (emphasis added).

158 Vienna Convention on the Law of Treaties 1155 UNTS 331 (23 May 1969). The Convention does not define the term "State", but commentary of the International Law Commission on the draft article that became art 6 explains that "[t]he term "State" ... means a State for the purposes of international law": Yearbook of the International Law Commission [1966] vol 2 YILC at 192. See generally Daniel Turp and François Roch "Article 6: Capacity of States to Conclude Treaties" in Olivier Corten and Pierre Klein (eds) The Vienna Conventions on the Law of Treaties: A Commentary (Oxford University Press, Oxford, 2011) at 107.

159 This path was forged by the Cook Islands. After the World Health Organisation accepted the Cook Islands' membership application in 1984, and its subsequent admittance to the Food and Agricultural Organisation of the United Nations (1985), United Nations Educational, Scientific and Cultural Organization (1985) and International Civil Aviation Organization (1986), the Secretary-General recognised it as a full member without any specifications or limitations in 1992 with full treaty-making capacity. The full treaty-making 
for the purpose of international law. ${ }^{160}$ Furthermore, "there is a clear tendency", explains Igarashi, "to recognize the international personality of Associated States as much as possible, once the right of self-determination has been established". 161

If the island-state chooses to become self-governing, it would proceed to the second stage of the model to define a new constitutional regime. Unlike the first stage, this process would be the sole domain of the newly self-governing state (or more precisely, its constituent or legislative assembly). There would be no established role for the external state in the deliberations for a new constitution (though external advice or funding voluntarily sought may be appropriate where this contributes to the people's constituent power). Following a participative and open constitution-making process, the people would be invited to vote on the proposed constitution in a second referendum. If affirmed, the proposed constitution would become supreme law by an action of the newly self-governing state's legislative assembly.

The question remaining regarding this proposed model is: if a state accepts a change in political status, in what form and under what authority does the political regime operate in the interim before a new constitution passes into force? In order to keep the process as simple as possible, it is desirable that the state's former governance structures continue to operate as per normal. For most former territories this would pose no problem as they function at the day-to-day level as selfgoverning states already. Where this is not the case, a basic interim constitution may need to be considered. ${ }^{162}$

In relation to constitution-making in small dependent states, several benefits flow from separating the decision regarding the political relationship with the external state from the

capacity of Niue was recognised by the Secretary-General in 1994. See Summary of Practice of the Secretary-General as Depositary of Multilateral treaties UN Doc ST/LEG/7/Rev 1 (1994) at [82]-[87]. The treaty-making capacity of the Cook Islands was made further clear in the Joint Declaration between the Cook Islands and New Zealand, which stipulates that "[t]he Government of the Cook Islands possesses the capacity to enter into treaties and other international agreements in its own right with governments and regional and international organisations." Joint Centenary Declaration of the Principles of the Relationship between New Zealand and the Cook Islands (Rarotonga, 11 June 2001) at cl 5. See generally Laws of New Zealand, above n 112, at [34].

160 The focus is on the competence of the particular associated State. Alison Quentin-Baxter explains: "the test is whether the associated State is competent to exercise, and does in fact exercise, responsibility for the conduct of its external relations in its own right and not as an organ of its partner State". See Laws of New Zealand, above n 112, at [34].

161 Masahiro Igarashi Associated Statehood in International Law (Kluwer Law International, Netherlands, 2002) at 300.

162 Interim Constitutions have been widely used, particularly in post-conflict situations, for example in South Africa (1993), Nepal (2007) and Iraq (2004). See generally Michele Brandt, Jill Cottrell, Yash Ghai and Anthony Regan Constitution-making and Reform: Options for the Process (Interpeace, Switzerland, 2011) at [2.1.9]. 
constitutional deliberations. For an external (former colonising) state, this model offers a means to engage in the decolonisation process so to discharge its "obligation to promote to the utmost ... well-being of the inhabitants of these territories", ${ }^{163}$ while ensuring that such involvement does not detract from the democratic legitimacy of the process overall. It also ensures that Principle VII(b) of General Assembly Resolution 1541, which states that an "associated territory should have the right to determine its internal constitution without outside interference, in accordance with due constitutional processes and the freely expressed wishes of the people", is afforded respect. ${ }^{164}$

For the island-state, by clearly delineating the stage at which the external state has a role, its influence can be contained and channelled so as to avoid a potential external exercise of constituent power. By determining the political status and future relationship with the external state in stage one, the local people's attention can be wholly focussed on constitutional design in stage two. The risk that the people may feel pressured to acquiesce to the external state's suggestions, or are in some way beholden to it, is significantly reduced. Having already determined the nature of the future relationship between the island-state and external state, decisions can be taken by the people without fear that those decisions may reduce their chances to continue receiving support from the external state.

For both states, providing a democratically legitimate avenue for the external state to be involved in the constitution-making process of the island-state ultimately fosters an enhancement of the latter's constituent power. For the most part, it is the non-self-governing state that wishes to maintain ongoing ties with an external state. To wholly exclude a role for an external state in the constitution-making process would therefore ultimately limit the options available for the non-selfgoverning island-state. With this in mind, stage one provides a democratically legitimate means for an external state to be involved in the constitution-making process. To ensure, however, that the constitution is an expression of popular constituent power, stage two provides a temporally distinct process for constitutional design which is the sole domain of the people.

\section{CONCLUSION}

Reflecting on the persistence of colonialism in the Pacific, Alison Quentin-Baxter makes the following comment: ${ }^{165}$

In very small islands that are still non-self-governing, the concern is not the continuation of colonial status. It is the possible ending of that status and with it the ending or substantial reduction of the administering power's present support. The real enemy is not present exploitation. It is future neglect.

163 Charter of the United Nations, art 73.

164 Principles which should guide members in determining whether or not an obligation exists to transmit the information called for under Article 73 e of the Charter, above n 12.

165 Quentin-Baxter, above n 152, at 3. 
Classical constituent power theory demands that a constitution be the product of a popular exercise of constituent power; an act of self-determination undertaken by the people, for the people. It has been argued that the existence of external influence in the constitution-making process is not necessarily at odds with this. This article has rejected generalised verdicts regarding external influence and advocated in favour of particularised assessment that takes as its focus the effect of external influence on the exercise of constituent power. The democratic legitimacy of the constitution-making process is dependent on the constitution being a manifestation of the people's constituent power. In so far as external actors do not displace the people's constituent power but rather enhance it, there is no reason to exclude such influence; there may even be reason to encourage it.

The Cook Islands and Niue, like many former non-self-governing territories, did not desire full independence at decolonisation. By seeking a relationship of free association with New Zealand that included shared citizenship and financial assistance, a role for New Zealand was expected and largely welcome throughout the respective island states' constitution-making processes. In neither instance, however, did New Zealand's role in the respective constitution-making processes enhance the people's constituent power, and in the case of the Cook Islands, New Zealand exercised a degree of constituent power.

New Zealand's more recent decolonising experience with Tokelau points towards a more promising approach to constitution-making in non-self-governing island states. Tokelau ultimately chose not to become an associated state. By drawing on its experience however, this article has advanced a two-stage model for constitution-making designed with the remaining 15 non-selfgoverning island states in mind. As ongoing political ties with an external state are often sought at decolonisation by such island states, the aim of the model is to provide an avenue for that external state to participate in or contribute to the constitution-making process while maintaining the process's democratic legitimacy.

The remaining non-self-governing communities of the 21 st century continue to respond to their political and social realities as best they can, with an aim of ensuring the brightest possible future for their future generations. For some, this has meant retaining colonial ties with an external actor. This article has not attempted to propose a model relationship of political association for such small dependent island states, but it has presented a model for constitution-making in the instance that they wish to go down that path. ${ }^{166}$

Listen and observe, assist when asked, find and smooth the way forward to a viable self-governing future for the territory - that is the role for those outside. The advisors will not live in the decolonised

$166 \mathrm{AH}$ Angelo "Statement by the Constitutional Adviser to the United Nations Committee of 24" (Pacific Regional Seminar, Nadi, 14-16 May 2002) in AH Angelo and A Townend Tokelau: A Collection of Documents and References Relating to Constitutional Development (4th ed, Law Publications, Wellington, 2003) at 193. 
territory, the United Nations Committee of 24 will not live there, the colonial governors or administrators will not live there - but, if Tokelau is the example, Tokelauans will. 